\title{
PRIME TIME
}

\section{Parental control.}

\section{BY JENNIFER CAMPBELL-HICKS}

A urelia's Dad stood on the basement stairs, his electrically charged hair bristled like porcupine quills. Behind him stood three more Dads who were exact copies of the first.

"Aurelia, thank goodness," said the Dads. "I'm still at - "

"The movie with Mom? Yep."

"Good. I used my time machine to come back and warn you. Tonight, before Mom and I get home, you will vanish without a trace." The Dad in front grabbed her shoulders. "Fate is not set. I'm here to change it. And stop biting your nails."

She snatched her fingers from her mouth. It was a coping mechanism. Senior year, harder classes, applying to colleges. There were no strategies for coping with this.

"You're 11A," she said. "11B, 11C, 11D."

They looked confused. "What?"

"Just follow me."

She led the four Dads to the living room. Six more copies sat on the leather couch, the love seat and the recliner. One leaned against the wall. They looked anxious. One Dad $3 \mathrm{~A}$, she thought - clicked the remote at the television.

"What's this?" the 11s asked.

"What do you think? Your machine is broken. It's spitting you out, over and over. You're coming out in groups so you always add up to a prime number. We had seven. Now it's eleven." She was proud that she had seen the pattern and gave credit to four years on the school maths team.

"Primes? Why?"

"How should I know? It's your stupid machine. And before you ask, because you've already asked, there are 10 of you here because $1 \mathrm{~A}$ is in the basement trying to shut down the machine." Her gaze slid over them. "You should have listened to Mom. She said it was a bad idea to mess with the space-time continuum."

Knocking shook the basement door.

"What was that?" a Dad asked.

"You," Aurelia said and gnawed at her thumbnail. "Have a seat. If there's one left."

Back in the kitchen, she opened the basement door. This time, as she expected, two Dads stood on the steps.

"Aurelia, thank goodness -"

"I know. I vanished. You're here to save me." She pointed. "13A and 13B. Come with me."

If this continued, dozens of Dads might be all over the house when her parents got

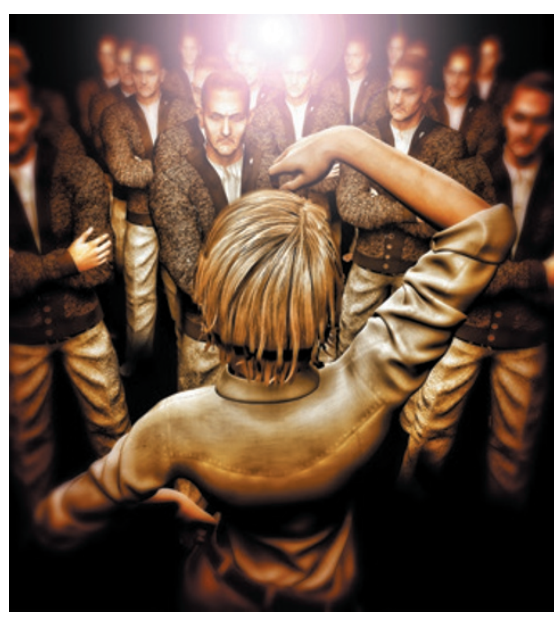

home. She ran the numbers: 17, 19, 23, 29, $31,37,41,43 \ldots$

"What's this?" the 13 s asked in the living room.

"The others will explain. I need a volunteer."

"Me," they all said.

She pointed. "Who are you?"

"11B."

"Come on."

In the basement, the time machine hummed and clicked. It was an 8-foot cube of metal, gears, wires and pulsating light with an open hatch. Soon, if nothing changed, four more Dads would emerge from the hatch. The timing wasn't regular. They could appear 10 seconds from now or 10 minutes. Dad 1A peered out from behind the machine, grease on his cheeks.

"There's something wrong, obviously," he said. "I can't shut off the power."

"It'll keep spitting you out?" Aurelia asked. He nodded.

"For how long? Eternity?"

"Or until the space-time continuum overloads. Can it do that? I don't know." He shook his head. "I should have listened to your mother. I'm sorry."

He looked so sad that Aurelia hugged him.

"I wish we had more time," 11B said.

That gave Aurelia an idea. "We do have time. I can jump forward and tell you not to jump back." Then she thought of something else. "Wait. That must be how I vanished in the first place, which was why you came back to save me."

11 B stepped forward. "I'll go."

"We can't meet ourself like that," said 1A. "Paradox risk."

Aurelia chewed on two fingernails at once. Was this how the apocalypse started? The world became overrun by crazy-haired clones of her Dad? Then she remembered what he had said on the basement steps. Fate was not set. They could change it.

"You can't shut off the machine," she said. "Can you send it to another time?"

"I don't know," Dad 1A said, sounding dubious, but Dad 11B grew excited. "We can program it so it's always five minutes from the present! If it's always five minutes in our future, it will never overrun our now with clones."

"And if I don't go to warn you," Aurelia added, "I won't disappear, which means you won't come here at all."

It was perfect. They could solve the problem before it started, but Dad 1A's shoulders slumped.

"If we send the machine to the future, I'll lose it. All those years of work will be for nothing."

"I’m sorry," Aurelia said. "It doesn't work right, anyway. The alternative is Dad clones coming out in primes into infinity. The Earth can't handle that."

He nodded. The two Dads got to work with the machine's controls while Aurelia watched with her hands stuck firmly under her armpits so she wouldn't chew on her nails. Then they said: "Ready to rock and roll. Be good, kiddo."

They pressed a button. The machine hummed louder, glowed brighter. Aurelia squeezed her eyes shut. When she opened them, the machine was gone, leaving a square of clean concrete floor amid the dust. The Dads were gone, too.

She sprinted upstairs. The living room was empty, thank goodness. Then a key turned in the front door. Aurelia's fingers rose to her mouth, but she stopped and put her hands at her sides. She could handle this. The door swung open. Dad walked in with Mom behind him, both in nice date-night clothes.

"Aurelia," Dad said. "It's a school night. Why aren't you in bed?"

She took a deep breath. "Dad, do you have time to talk?" -

Jennifer Campbell-Hicks is a writer, journalist, wife, mother and lifelong fan of science fiction and fantasy. Her fiction has appeared in Daily Science Fiction, Flash Fiction Online and Intergalactic Medicine Show. She blogs at jennifercampbellhicks. blogspot.com. 